\title{
PROGRESSIVE MUSCLE RELAXATION UNTUK MEMBANTU MENURUNKAN KECEMASAN PADA IBU MENYUSUI SELAMA POSTPARTUM
}

\author{
Progressive Muscle Relaxation to Help decrease Anxiety Breast Feeding Mother \\ During Post Partum
}

\author{
Nevy Norma Renityas ${ }^{1}$, Ika Agustina ${ }^{2}$ \\ Program Studi Kebidanan Stikes Patria Husada Blitar \\ Alamat Korespondensi : STIKes Patria Husada, \\ J1.Sudanco Supriyadi No.168 Blitar., Telp./Faks.(0342)814086 \\ email : nevy200385@gmail.com
}

\begin{abstract}
ABSTRAK
ASI (Air Susu Ibu) merupakan bahan makanan utama bagi bayi usia 0-6 bulan dimana ASI akan memenuhi kebutuhan nutrisi (Rahayu et al.2015; Pollard, 2015 dalam Saraung et al 2017). Menyusui adalah proses pemberian susu kepada bayi atau anak kecil dengan air susu ibu (ASI) dari payudara ibu. Bayi menggunakan refleks menghisap untuk mendapatkan dan menelan susu. Stres dan cemas sering ibu alami dalam menyusui terutama dialami pada ibu postpartum satu minggu setelah melahirkan. PMR(Progressive Muscle Relaxtation) adalah teknik yang bermanfaat untuk mengurangi stres dan kecemasan di tubuh kita dengan cara menegangkan dan mengendurkan otot secara perlahan-lahan. Latihan ini dapat membantu ibu menyusui untuk segera merasa rileks. Desain penelitian yang peneliti gunakan adalah eksperimental jenis posttest only-nonequivalent control group design sampel diambil dari ibu post partum di Puskesmas Ponggok Kabupaten Blitar yang memenuhi criteria inklusi yaitu kelompok perlakukan dan kelompok control. Pengambilan sampel dengan cara purposive sampling, jumlah populasi 92 ibu post partum dan sampel 48 responden yang terbagi atas kelompok perlakuan dan control di Puskesmas Ponggok Kabupaten Blitar. Instrument penelitiannya berupa Post Partum Specific Anxiety Scale (PSAS) dan Pittsburgh Sleep Quality Index (PSQI) (Fallon et al., 2016). Hasil penelitian ini menunjukkan ada pengaruh yang signifikan Progresive Muscle Relaxation terhadap kecemasan ibu menyusui di Puskesmas Ponggok Kabupaten Blitar ditunjukkan dengan dan nilai $(p$-value $=0,001)<(\alpha=0,05)$.
\end{abstract}

\section{Kata Kunci: kecemasan ibu menyusui, Progresive Muscle relaxtation}

\begin{abstract}
Breast milk (breast milk) is the main food ingredient for babies aged 0-6 months where breast milk will meet nutritional needs (Rahayu et al. 2015; Pollard, 2015 in Saraung et al 2017). Breastfeeding is the process of giving milk to a baby or small child with breast milk (ASI) from the mother's breast. Babies use the sucking reflex to get and swallow milk. Stress and anxiety often experienced by mothers in breastfeeding, especially experienced in postpartum mothers one week after giving birth. PMR (Progressive Muscle Relaxtation) is a useful technique for reducing stress and anxiety in our body by slowly tensing and relaxing muscles. This exercise can help nursing mothers to feel relaxed immediately. The research design that the researchers used was an experimental type of posttest only-nonequivalent control group. The sample design was taken from post partum mothers in Ponggok Health Center, Blitar Regency, who met the inclusion criteria, namely the treatment group and the control group. Sampling was done by purposive sampling, the total population was 92 post partum mothers and a sample of 48 respondents which were divided into treatment and control groups at Ponggok Health Center, Blitar Regency. The research instruments were the Post Partum Specific Anxiety Scale (PSAS) and the Pittsburgh Sleep Quality Index (PSQI) (Fallon et al., 2016). The results of this study indicate that there is a significant effect of Progressive Muscle Relaxation on the anxiety of breastfeeding mothers at Ponggok Health Center, Blitar Regency indicated by and the value $(p$-value $=0.001)<(\alpha=0.05)$.
\end{abstract}

Keywords: Breast Feeading, Progresive Muscle Relaxtation 


\section{PENDAHULUAN}

ASI (Air Susu Ibu) merupakan bahan makanan utama bagi bayi usia 0-6 bulan dimana ASI akan memenuhi kebutuhan nutrisi (Rahayu et al.2015; Pollard, 2015 dalam Saraung et al 2017). ASI mengandung berbagai zat seperti protein, lemak, karbohidrat, mineral, vitamin yang dibutuhkan bayi untuk pertumbuhan dan perkembangan serta sesuai dengan kebutuhan bayi seperti mengurangi angka kematian bayi baru lahir terutama pada pemberian ASI satu jam pertama setelah kelahiran, mengurangi insidensi maloklusi gigi, meningkatkan kecerdasan, memberikan kekebalan dan meningkatkan ikatan antara ibu dan anak (Parwati et al, 2017). Menyusui adalah proses pemberian susu kepada bayi atau anak kecil dengan air susu ibu (ASI) dari payudara ibu. Bayi menggunakan refleks menghisap untuk mendapatkan dan menelan susu. Menyusui setiap dua-tiga jam akan menjaga produksi ASI tetap tinggi. Untuk wanita pada umumnya, menyusui atau memerah ASI delapan kali dalam 24 jam akan menjaga produksi ASI tetap tinggi pada masa-masa awal menyusui, khususnya empat bulan pertama. Bukanlah hal yang aneh apabila bayi yang baru lahir menyusui lebih sering dari itu, karena rataratanya adalah 10-12 kali menyusui tiap 24 jam, atau bahkan 18 kali. Menyusui ondemand adalah menyusui kapanpun bayi meminta (artinya akan lebih banyak dari ratarata) adalah cara terbaik untuk menjaga produksi ASI tetap tinggi dan bayi tetap kenyang Tetapi perlu diingat, bahwa sebaiknya menyusui dengan durasi yang cukup lama setiap kalinya dan tidak terlalu sebentar, sehingga bayi menerima asupan foremilk dan hindmilk secara seimbang
Keluarnya hormon oksitosin menstimulasi turunnya susu (milk ejection / let-down reflex). Oksitosin menstimulasi otot di sekitar payudara untuk memeras ASI keluar. Para ibu mendeskripsikan sensasi turunnya susu dengan berbeda-beda, beberapa merasakan geli di payudara dan ada juga yang merasakan sakit sedikit, tetapi ada juga yang tidak merasakan apa-apa. Refleks turunnya susu tidak selalu konsisten khususnya pada masa-masa awal. Tetapi refleks ini bisa juga distimulasi dengan hanya memikirkan tentang bayi, atau mendengar suara bayi, sehingga terjadi kebocoran. Sering pula terjadi, payudara yang tidak menyusui bayi mengeluarkan ASI pada saat bayi menghisap payudara yang satunya lagi. Lama kelamaan, biasanya setelah dua minggu, refleks turunnya susu menjadi lebih stabil. Refleks turunnya susu ini penting dalam menjaga kestabilan produksi ASI, tetapi dapat terhalangi apabila ibu mengalami stres. Oleh karena itu sebaiknya ibu tidak mengalami stres. Refleks turunnya susu yang kurang baik adalah akibat dari puting lecet, terpisah dari bayi, pembedahan payudara sebelum melahirkan, atau kerusakan jaringan payudara. Apabila ibu mengalami kesulitan menyusui akibat kurangnya refleks ini, dapat dibantu dengan pemijatan payudara, penghangatan payudara dengan mandi air hangat, atau menyusui dalam situasi yang tenang. Faktor lain yang dapat mempengaruhi produksi ASI yaitu faktor fisik dan faktor psikis. Terkait faktor fisik ibu yaitu adalah status kesehatan ibu, umur dan paritas, asupan nutrisi dan cairan, faktor merokok, nyeri luka operasi. Nyeri luka operasi bisa disebabkan karena tindakan Sectio 
Caesarea/nyeri jahitan pada jalan lahir setelah melahirkan. Terkait faktor psikis ibu seperti kecemasan. Akibat dari kecemasan ibu dapat menghambat produksi ASI. Untuk memproduksi ASI ibu harus mendapatkan rangsangan pada payudara, respon dari rangsangan tersebut akan dikirim ke hipofisis untuk pengeluaran dan produksi air susu yang disebut laktasi (Ariani, 2009).

Stres dan cemas sering ibu alami dalam menyusui terutama dialami pada ibu postpartum satu minggu setelah melahirkan. PMR(Progressive Muscle Relaxtation) adalah teknik yang bermanfaat untuk mengurangi stres dan kecemasan di tubuh kita dengan cara menegangkan dan mengendurkan otot secara perlahan-lahan. Latihan ini dapat membantu seseorang untuk segera merasa rileks. Pada ibu menyusui bisa melakukan PMR. Jadi caranya, tutup mata dan mulailah menarik napas dalam. Kemudian mulailah dengan menekuk jari-jari kaki Anda selama 10 detik, buang napas saat mengendurkannya selama 25 detik. Lakukan gerakan ini ke seluruh tubuh secara bertahap. Lakukan selama 25-30 menit.

\section{METODE}

Desain penelitian yang peneliti gunakan adalah eksperimental jenis posttest onlynonequivalent control group design sampel diambil dari ibu post partum di Puskesmas Ponggok Kabupaten Blitar yang memenuhi criteria inklusi yaitu kelompok perlakukan dan kelompok control. Pengambilan sampel dengan cara purposive sampling, jumlah populasi 92 ibu post partum dan sampel 48 responden yang terbagi atas kelompok perlakuan dan control di Puskesmas Ponggok Kabupaten Blitar.
Instrument penelitiannya berupa Post Partum Specific Anxiety Scale (PSAS) dan Pittsburgh Sleep Quality Index (PSQI) (Fallon et al., 2016). Dimana hasil uji validitas untuk sampel pada taraf signifikan $5 \%$ didapatkan nilai dari uji sebelumnya didapatkan $0,302-0,792$, maka kuesioner tersebut dikatakan valid. Evaluasi konsistensi yang dilakukan menggunakan rumus Alpha Cronbach yaitu mengidentifikasi konsistensi internal pada setiap item pernyataan, hasil dari uji sebelumnya adalah $r=0,933$. Dari hasil perhitungan, didapatkan $r$ hitung lebih besar dari $r$ tabel, maka instrumen dikatakan reliabel. Pelaksanannya yaitu penilaian PASS diberikan saat pertama kali bertemu dengan pasien. Lalu pasien diberikan penjelasan terkait manfaat relaksasi otot progresif. Ibu post partum yang mengatakan tertarik dan mengatakan akan mencoba rutin melaksanakannya setiap hari. Pelaksanaan relaksasi otot progresif dilakukan dalam kondisi nyaman dan rileks, pejamkan kedua mata,dengan melatih otot pada anggota tubuh seperti otot tangan (bisep), otot wajah, otot bahu, leher, punggung, dada dan kaki disertai dengan menarik nafas dalam melalui hidung selama 4 detik/hitungan sampai dada dan abdomen terasa terangkat maksimal, jaga mulut tetap tertutup selama menarik nafas (inspirasi), tahan nafas selama 2 detik/hitungan, menghembuskan nafas melalui bibir yang dirapatkan dan sedikit terbuka dalam 4 detik/hitungan, Istirahat selama 2 detik/hitungan dengan nafas biasa, ulangi sebanyak $5 x$ (nafas dalam 5x selama 1 menit), sebanyak 5 siklus selama 15 menit, 2 kali sehari, selama 3 hari. Evaluasi hasil dilakukan saat klien sudah berada di rumah, dengan melakukan kunjungan rumah. Analisis data menggunakan uji statistic 
Independent t-test dan Dependent t-test. Kriteria inklusi dalam penelitian adalah ibu primipara, ibu yang bisa membaca dan menulis, ibu dalam keadaan sadar, ibu yang mau memberikan ASI dan menjalani Inisiasi Menyusui Dini, serta ibu yang memilki bayi dengan badan lahir 25004000gr, ibu yang mau menyusui bayi dengan eksklusif tanpa diberi makanan tambahan lain. Kriteria eksklusi ibu postpartum yang tidak sadar, mempunyai gangguan mental, ibu postpartum yang mempunyai kelainaan payudara, ibu postpartum yang kontraindikasi terhadap progressive muscle relaxation.

\section{HASIL DAN PEMBAHASAN}

TABEL 1

Karaktristik responden $(\mathrm{n}=48)$

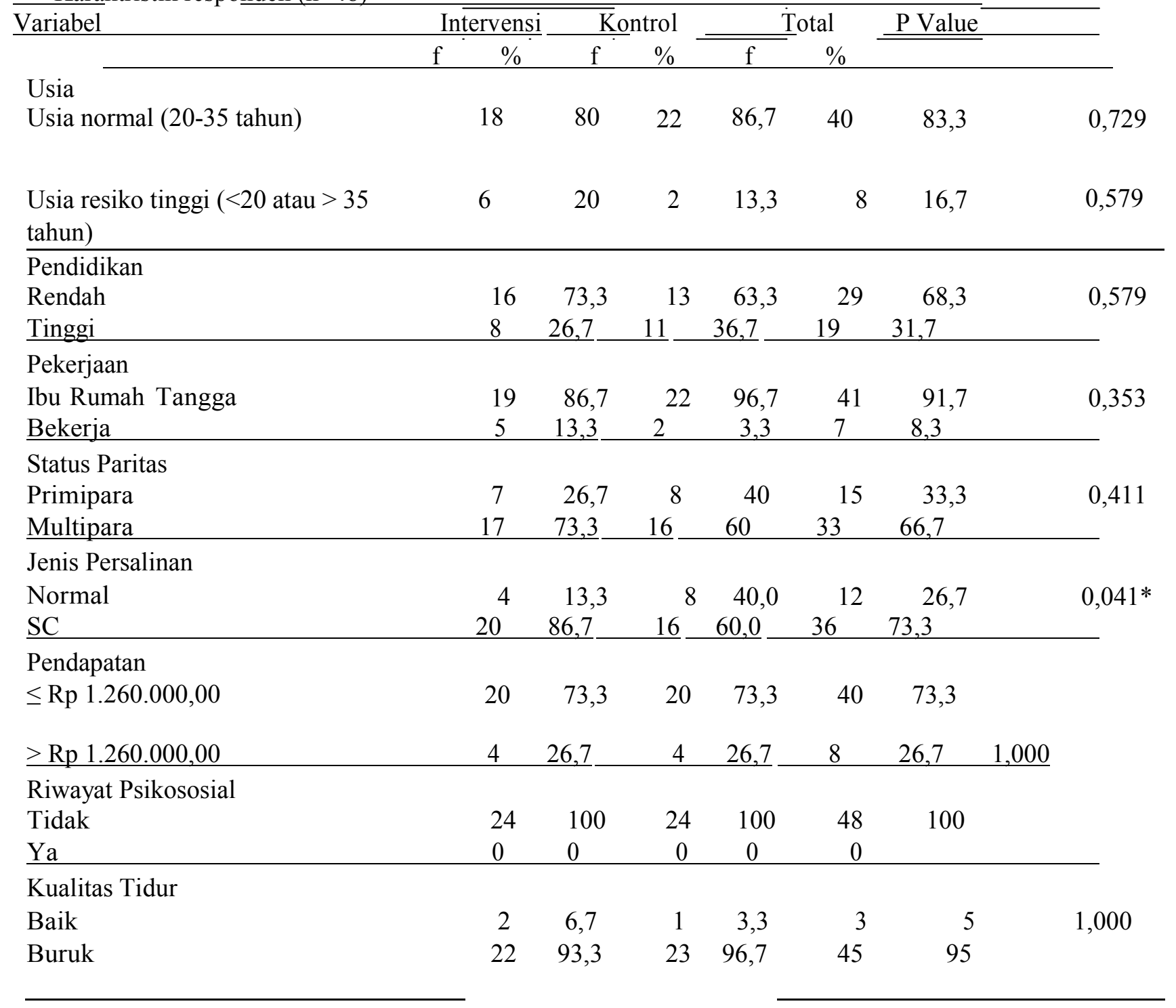

Dari tabel 1: menunjukkan bahwa usia responden 20-35 tahun sebanyak $83,3 \%$, usia resiko tinggi(umur $<20$ tahun dan $>35$ tahun) sebanyak $16,7 \%$, sedangkan untuk pendidikan rendah sejumlah 68,3 serta pendidikan tinggi sejumlah 31,7\%,Pekerjaan pada kelompok kontrol sama seperti kelompok intervensi sebagian besar ibu rumah tangga. Pada status 
paritas kelompok kontrol dan kelompok intervensi sebagian besar multipara. Jenis persalinan pada kelompok kontrol dan kelompok intervensi sebagian besar SC. Pendapatan baik kelompok kontrol maupun kelompok intervensi sebagian besar pendapatan $\leq \mathrm{Rp} 1.260 .000,00(\mathrm{UMR}$
Kabupaten Blitar). Riwayat psikososial kelompok kontrol dan kelompok intervensi semuanya tidak memiliki riwayat. Bantuan sosial pada kelompok kontrol dan kelompok intervensi semuanya mendapatkan bantuan sosial. Kualitas tidur pada kelompok kontrol dan kelompok intervensi sebagian besar buruk.

TABEL 2

Perbedaan kecemasan ibu menyusui sebelum dan setelah diberikan progressive muscle relaxation pada kelompok intervensi

\begin{tabular}{|c|c|c|c|c|c|c|}
\hline Variabel & Perlakuan & Mean & Std deviasi & Mean different & $t$ & p-value \\
\hline $\begin{array}{l}\text { Kecemasan } \\
\text { ibu }\end{array}$ & Sebelum & $24 \quad 34,21$ & 15,522 & 11,237 & 3,321 & 0,001 \\
\hline Menyusui & Setelah & $24 \quad 23,69$ & 14,664 & & & \\
\hline
\end{tabular}

Tabel 2 Menjelaskan ada perbedaan yang sangat significant antara ibu menyusui sebelum dan sesudah pemberian progresife muscle relaxation dengan rata-rata mean sebelum intervensi 34,21 dan setelah intervensi 23, 69
Hal ini berarti ada perbedaan kecemasan yang signifikan Sebelum dan Setelah diberikan progressive muscle relaxation di Puskesmas Ponggok.,pada Kelompok Intervensi

\section{TABEL 3}

Perbedaan Kecemasan ibu menyusui Sebelum dan Setelah diberikan terapi relaksasi otot progresif pada kelompok kontrol

\begin{tabular}{|c|c|c|c|c|c|c|}
\hline & \multicolumn{5}{|c|}{ otot progresif pada kelompok kontrol } & \\
\hline Variabel & Perlakuan $N$ & Mean & Std deviasi & Mean different & ${ }_{t} t$ & $p$-value \\
\hline Intensitas Nyeri & Sebelum 24 & 31,76 & 10,674 & 0,087 & 0,180 & 0,433 \\
\hline & Setelah & 32,45 & 9,478 & & & \\
\hline
\end{tabular}

Tabel 3 menjelaskan tidak ada perbedaan yang signifikan kecemasan ibu menyusui sebelum dan sesudah pemberian progressive muscle relaxtation dengan rata-rata mean sebelum intervensi 31,76 dan setelah intervensi 32,45 dengan nilai $(p$-value $=0,433)$ $>(\alpha=0,05)$. Hal ini berarti tidak ada perbedaan kecemasan ibu post partum yang signifikan Sebelum dan Setelah diberikan terapi relaksasi otot progresif muscle relaxation di Puskesmas Ponggok kabupaten blitar. pada kelompok kontrol.

\section{Tabel 4}

Selisih rerata kecemasan ibu postpartum pada kelompok intervensi dan kelompok kontrol

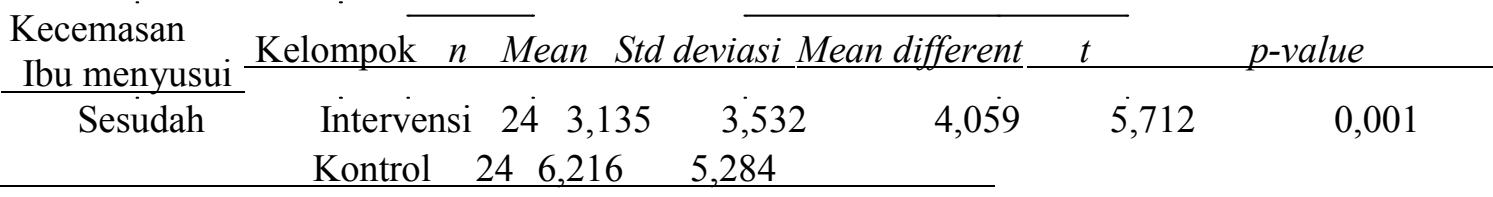


Tabel 4 dapat diketahui rata-rata intensitas nyeri pada kelompok intervensi sebesar 3,135 dan rata-rata kecemasan pada kelompok kontrol 6,216 sedangkan perbedaan rata-rata (Mean different) sebesar 4,059 dan

\section{PEMBAHASAN}

\section{Perbedaan Sebelum dan Setelah} Diberikan Progresife Muscle Relaxation pada Ibu Menyusui

Berdasarkan hasil penelitian menjelaskan ada perbedaan yang signifikan kecemasan ibu menyusui sebelum dan sesudah pemberian Progresife Muscle Relaxation dengan rata-rata mean sebelum intervensi 34,21 dan setelah intervensi 23, 69 dengan nilai $(p$-value $=0,001)<(\alpha=0,05)$. Hal ini berarti ada perbedaan kecemasan yang signifikan Sebelum dan Setelah diberikan Progresive Muscle Relaxation di Puskesmas Ponggok Kabupaten Blitar. Hasil penelitian tersebut sejalan dengan penelitian (Golmakani, Sadat, Ahmadi, Taghi, \& Pour, 2015) bahwa terapi relaksasi otot progresif $(P M R)$ merupakan cara yang dapat digunakan untuk meringankan kecemasan ibu intranatal primigravida kala pertama dengan nilai $(p-$ value $=0,001)<(\alpha=0,05)$. karena pada penelitian ini relaksasi otot progresif dapat menurunkan ketegangan otot dan juga dapat menurunkan kecemasan sehingga membuat tubuh menjadi relaks. Kondisi relaks akan menurunkan respon fisik berupa penurunan denyut nadi, denyut jantung serta pernafasan. Pada saat kondisi relaks, aliran darah akan menyebar secara merata, sehingga sirkulasi darah menjadi lancar. Kondisi relaks secara fisik juga akan membawa kondisi relaks secara psikologis, sehingga dapat menurunkan nilai $(p$-value $=0,001)<(\alpha=0,05)$. Hal ini berarti ada pengaruh yang signifikan progressive muscle relaxaxation terhadap kecemasan ibu menyusui di PKM ponggok Kabupaten Blitar.

kecemasan dan depresi. Berdasarkan hasil penelitian menjelaskan tidak ada perbedaan yang signifikan kecemasan ibu menyusui sebelum dan sesudah pemberian terapi Progresive Muscle Relaxation dengan rata-rata mean sebelum intervensi 31,76 dan setelah intervensi 32,45 dengan nilai $(p$-value $=0,433)$ $>(\alpha=0,05)$. Hal ini berarti tidak ada perbedaan kecemasan ibu menyusui yang signifikan Sebelum dan Setelah diberikan terapi relaksasi otot progresif di Puskesmas Ponggok pada Kelompok Kontrol. Perubahan psikologis pada ibu menyusui dapat diikuti dengan kejadian depresi. 2\% ibu baru didiagnosis dengan depresi mayor atau minor dalam tiga bulan pertama pasca persalinan, dan $7,1 \%$ secara khusus dengan depresi berat. Dalam penelitian lain terhadap 214 wanita, 86 melaporkan gejala depresi tingkat tinggi $(40,2 \%)$, namun hanya 25 wanita $(1,7 \%)$ yang benar-benar didiagnosis mengalami depresi. Survei lain mengungkapkan bahwa sepertiga dari skor wanita dalam rentang depresi pada delapan bulan pasca persalinan masih tertekan 12-18 bulan kemudian, namun hanya $15 \%$ yang mencari pertololongan atau dirujuk ke tempat pelayanan kesehatan mental professional.

Hal tersebut juga sesuai dengan penelitian di Universitas George Town Amerika Serikat, sebanyak 212 studi dengan hasil 75\% telah ada peningkatan kecemasan yang cukup serius terhadap para ibu hamil yang berada di dalam 
lapas dan komitmen agama membantu menurunkan kecemasan tersebut menunjukkan pengaruh positif. Hasil survey oleh majalah Time dan CNN serta USA Weekend tahun 1996, menyatakan bahwa lebih 70 pasien percaya bahwa dengan relaksasi dengan menenangkan pikiran (Thurgood, S., Avery, D. M., \& Williamson, 2009). Hal tersebut juga sesuai dengan di Universitas George Town Amerika Serikat, sebanyak 212 studi dengan hasil $75 \%$ telah ada peningkatan kecemasan yang cukup serius terhadap pada ibu hamil yang berada di dalam lapas dan dengan relaksasi otot progresif dapat meningkatkan ketenangan dan menurunkan kecemasan dapat menunjukkan pengaruh positif (Golmakani et al., 2015). Menurut (Fallon et al., 2016) yang tidak jelas dan menyebar, berkaitan dengan perasaan tidak pasti dan tidak berdaya. Keadaan emosi ini tidak memiliki obyek yang spesifik, dialami secara subyektif dan dikomunikasikan secara interpersonal. Respon individu bersifat unik dan membutuhkan pendekatan yang unik pula. Salah satu terapi spesialis keperawatan sebagai manajemen ansietas adalah dengan progressive muscle relaxation yang merupakan bagian dari terapi relaksasi. Penggunaan relaksasi dalam bidang klinis telah dimulai semenjak awal abad 20 ketika Edmund Jacobson melakukan penelitian dan dilaporkan dalam sebuah buku Progressive Relaxation yang diterbitkan oleh Chicago University Press pada tahun1938. Jacobson menjelaskan mengenai hal- hal yang dilakukan seseorang pada saat tegang dan rileks. Pada saat tubuh dan pikiran rileks, secara otomatis ketegangan yang seringkali membuat otot-otot mengencang akan diabaikan (Gökşin \& Ayaz-Alkaya, 2018). Progressive muscle relaxation adalah terapi relaksasi dengan gerakan mengencangkan dan melemaskan otot-otot pada satu bagian tubuh pada satu waktu untuk memberikan perasaan relaksasi secara fisik. Gerakan mengencangkan dan melemaskan secara progresif kelompok otot ini dilakukan secara berturut-turut(Ahmadi et al., 2019). Periode postpartum menuntut ibu untuk beradaptasi terhadap beberapa perubahan setelah melahirkan. Perubahan fisiologis yang terjadi pada ibu selama periode postpartum meliputi perubahan adaptasi fisik yang dapat memengaruhi keadaan psikologis ibu (Ospina, A., Muñoz, L., \& Cardenas, 2012). Perubahan psikologis terjadi secara simultan, dapat berupa emosional atau cemas, dengan membentuk suatu adaptasi yang menyeluruh atau cukup kompleks bagi ibu(Lowdermilk, Perry, 2013). Pada latihan relaksasi otot progresif ini perhatian individu diarahkan untuk membedakan perasaan yang dialami saat kelompok otot dilemaskan dan dibandingkan ketika otot-otot dalam kondisi tegang. Dengan mengetahui lokasi dan merasakan otot yang tegang, maka kita dapat merasakan hilangnya ketegangan sebagai salah satu respon kecemasan dengan lebih jelas, ketika kecemasan berkurang status kesehatan psikologis ibu pun meningkat sehingga berimbas pada meningkatnya status kesehata anaknya(Muller \& Hammill, 2015) 


\section{Pengaruh Progresive Muscle Relaxtation terhadap Kecemasan pada Ibu Menyusui.}

Berdasarkan tabel 3 dapat diketahui rata- rata intensitas nyeri pada kelompok intervensi sebesar 3,135 dan rata-rata kecemasan pada kelompok kontrol 6,216 sedangkan perbedaan rata-rata (Mean different) sebesar 4,059 dan nilai $(p$-value $=0,001)<(\alpha=$ 0,05). Hal ini berarti ada pengaruh yang signifikan Progresive Muscle Relaxtation terhadap kecemasan ibu menyusui di PKM Ponggok Kabupaten Blitar. Terapi Relaksasi Otot Progresif merupakan gerakan dan latihan pernapasan dengan tehnik bernafas secara perlahan dan dalam menggunakan otot pernafasan, sehingga memungkinkan abdomen terangkat perlahan dan dada mengembang penuh, menahan inspirasi secara maksimal dan kemudian menghembuskan nafas secara perlahan Secara umum tujuan relaksasi adalah untuk mengurangi tingkat kecemasan dalam hal fisiologis individu dan membawa individu ke keadaan yang lebih tenang baik secara fisik maupun psikologis. Salah satu gangguan psikologis yang dialami ibu postpartum adalah kecemasan. (Ahmadi et al., 2019) menyatakan bahwa $20 \%$ dari wanita paska persalinan mengalami gangguan perasaan (Golmakani et al., 2015). paska melahirkan dengan gejala kecemasan dan panic. Hal yang samapun disebutkan oleh (Rahmawati et al.,2017) bahwa diperkirakan terdapat 10 dari 40 orang ibu paska melahirkan mengalami depresi post partum. Sedangkan kasus yang terjadi setelah postpartum adalah baby blues dengan presentase sebanyak 50-80\%. Kecemasan yang terjadi pada periode post partum disebabkan karena adanya proses transisi menjadi orang tua, terjadi penyesuaian diri yang besar diantara hubungan mereka dan orang lain. Pada ibu post partum dapat terjadi kelelahan, perubahan peran, perubahan mood, seperti kesedihan dan kecemasan, karena periode post partum dikenal sebagai perubahan nyata yang membutuhkan penyesuaian diri yang besar diantara hubungan mereka dan orang lain. Pada ibu post partum dapat terjadi kelelahan, perubahan peran, perubahan mood, seperti kesedihan dan kecemasan, karena periode postpartum dikenal sebagai perubahan nyata yang membutuhkan penyesuaian dan dapat mempengaruhi fisik serta emosional (Muller \& Hammill, 2015). Sebagian besar ibu setelah melahirkan mengalami kecemasan postpartum berkelanjutan pada minggu pertama. Tekanan yang dirasakan tinggi dan dukungan social pasangan yang rendah dapat digunakan untuk identifikasi awal ibu yang mengalami kecemasan terus-menerus pada periode post partum dan menyarankan perlunya ke layanan psikoterapi. Faktor-faktor ini juga menjadi target terapi individu atau pasangan untuk mengobati kecemasan postpartum (Thurgood, S., Avery, D. M., \& Williamson, 2009). Kebutuhan spiritual berbanding lurus dengan kecemasan, jika kecemasan meningkat, maka kebutuhan spiritual terbesar adalah ibu post partum. Pada ibu postpartum merupakan puncak dari kecemasan dan akan muncul gejolak perasaan baru pada calon bayi sekaligus perasaan khawatir pada proses masa nifasnya. Terpenuhinya kebutuhan spiritualitas pada masa nifas, akan sangat menjaga perkembangan bayi. Selain itu, terpenuhinya kebutuhan psikologis juga dapat mencegah ibu mengalami Syndrom 
blue s(Thurgood, S., Avery, D. M., \& Williamson, 2009). Adaptasi psikologis yang kurang berhasil menyebabkan kecemasan ataupun depresi pada ibu postpartum, berdampak pada bayi terutama terkait dengan bonding attachment,sehingga anaknya cenderung mengalami perkembangan yang merugikan. Penelitian yang dilakukan oleh (Shaw et al2013)menemukan bahwa gangguan psikologis pada ibu postpartum seperti depresi atau postpartum blues berhubungan dengan bonding attachment pada bayi. Awitan dari kejadian postpartum blues karena ketidakmampuan ibu untuk melakukan adaptasi pasca persalinan. Ibu postpartum dengan kondisi depresi dan kecemasan juga berdampak negatif bagi ibu sendiri, diantaranya meningkatkan risiko penyakit mental kronis, menghambat perawatan diri, memengaruhi pemulihan periode postpartum, daya tahan tubuh/imunitas menurun, dan status kesehatan ibu menurun bahkan memburuk. Beberapa dampak tersebut saling memengaruhi dan berinteraksi satu dengan yang lainnya. Ibu postpartum yang mengalami gangguan psikologis dapat menyebabkan ibu berperilaku acuh terhadad perawatan dirinya sendiri. Selain itu pemenuhan kebutuhan diri juga terganggu, seperti pemenuhan nutrisi, kebutuhan istirahat dan tidur. Sehingga memengaruhi kesehatan fisik ibu, bahkan terjadi penurunan imunitas atau daaya tahan tubuh ibu. Hal tersebut terjadi saling memengaruhi dan terkait satu dengan yang liannya, membentuk siklus yang tidak terputus yang disebut psikonueroimunologi. Siklus tersebut jika berlanjut dalam jangka waktu panjang dapat menyebabkan komplikasi bahkan terjadi kematian. Psikoneuroimunologi merupakan mekanisme interaksi antara perilaku, sistem saraf, sistem endokrin, dan fungsi imun. Oleh karena itu, perlu pemutusan siklus tersebut (Fallon et al., 2016). Kondisi kecemasan seorang ibu postpartum yang berkelanjutan berdampak negatif bagi perkembangan selanjutnya, baik untuk ibu sendiri maupun bagi bayinya. Ibu menyusui dengan gangguan psikologis dapat memberi pengaruh buruk terhadap perkembangan kesehatan mental, gangguan jalinan ikatan dan perlekatan, kurangnya perawatan diri ibu dan bayi(Kirana, 2015). Oleh karenanya, kecemasan ibu menyusui harus sedini mungkin bisa diatasi. Hal ini imaksudkan agar kondisi ibu dan bayi tetap tumbuh kembang dengan baik. Penelitian yang dilakukan oleh menemukan bahwa relaksasi otot progresif mampu menurunkan tingkat kecemasan pada ibu post sectio caesarea(Gökşin \& Ayaz- Alkaya, 2018). Penelitian yang dilakukan (Sumantri, Susilowati, D., \& Wati, 2016) menemukan bahwa ada pengaruh totok wajah terhadap penurunan kecemasan ibu nifas. Penelitian (Gökşin \& Ayaz-Alkaya, 2018) menemukan bahwa terapi relaksasi dan latihan mobilisasi mampu menurunkan stres pada ibu postpartum. Penelitian (Muller \& Hammill, 2015) menemukan bahwa terapi relaksasi otot progresif mampu menurunkan stres dan kecemasan pada ibu maternal. Berdasarkan beberapa hasil penelitian tersebut dapat dinyatakan bahwa berbagai terapi relaksasi otot progresif cukup efektif untuk menurunkan kecemasan, artinya secara non farmakologis mampu menggantikan terapi farmakologis, yang dikhawatirkan dapat memberikan efek samping 
tertentu yang tidak baik bagi kesehatan ibu postpartum dengan menyusui bayi.

Berkaitan dengan kondisi tersebut, maka dalam penelitian ini dilakukan relaksasi otot progresif pada ibu postpartum. Relaksasi otot progresif merupakan latihan pernapasan dengan teknik bernapas secara perlahan dandalam, menggunakan otot diafragma, sehingga memungkinkan abdomen terangkat perlahan dan dada mengembang penuh (Arlinghaus, K. R., Markofski, M. M., \& Johnston, 2017) Menurut Priyanto (2010) relaksasi merupakan salah satu latihan pernafasan dengan menggunakan pernafasan diafragma dan kontraksi otot abdomen. Relaksasi otot progresif banyak dikembangkan dalam kajian keperawatan sebagai terapi penunjang. Latihan ini bertujuan untuk meningkatkan kemampuan otot-otot pernafasan yang berguna untuk meningkatkan compliance paru.Relaksasi relaksasi otot progresif ini telah terbukti mampu menjadi salah satu metode pengobatan. Penelitian yang dilakukan oleh (Rahayu \& Dwi Heppy Rochmawati, 2014) menemukan bahwa terbukti relaksasi otot progresif mampu menurunkan kecemasan pasien pre operasi bedah. Penelitian yang dilakukan oleh (Rahayu \& Dwi Heppy Rochmawati, 2014) menemukan bahwa terapi relaksasi otot progresif terbukti mampu menurunkan nyeri kepala akut pada pasien diabetes melitus. Penelitian Sepdianto (2010) menemukan bahwa terapi relaksasi otot progresif mampu menurunkan tekanan darah dan tingkat kecemasan pasien hipertensi primer di Kota Blitar. Penelitian Sellakumar dan Kannaiah
(2015) menemukan bahwa latihan relaksasi otot progresif mampu menurunkan tingkat kecemasan pada siswa remaja. Pada latihan relaksasi otot progresif ini perhatian individu diarahkan untuk membedakan perasaan yang dialami saat kelompok otot dilemaskan dan dibandingkan ketika otot-otot dalam kondisi tegang. Dengan mengetahui lokasi dan merasakan otot yang tegang, maka kita dapat merasakan hilangnya ketegangan sebagai salah satu respon kecemasan dengan lebih jelas, ketika kecemasan berkurang status kesehatan psikologis ibu pun meningkat sehingga berimbas pada meningkatnya status kesehata anaknya (Ahmadi et al., 2019) Berdasarkan hasil penelitian tersebut maka disarankan bagi ibu menyusui dapat memanfaatkan Progresive Muscle Relaxatation sebagai terapi komplementer untuk mengurangi kecemasan pada ibu menyusui dan Sebaiknya pelayanan kesehatan memberikan penyuluhan dan simulasi Progresive Muscle Relaxation secara berkesinambungan untuk menambah wawasan tenaga kesehatan tentang cara mengurangi kecemasan pada ibu menyusui selama post partum.

\section{KESIMPULAN}

Hasil penelitian ini menunjukkan ada pengaruh yang signifikan Progresive Muscle Relaxation terhadap kecemasan ibu menyusui di Puskesmas Ponggok Kabupaten Blitar ditunjukkan dengan dan nilai $(p$-value $=$ $0,001)<(\alpha=0,05)$. 


\section{DAFTAR PUSTAKA}

Ahmadi, M., Rahimi, F., Rosta, F., AlaviMajd, H., \& Valiani, M. (2019). Effect of Progressive Muscle Relaxation Training on Postpartum Blues in High-risk Pregnant Women. Journal of Holistic Nursing and Midwifery, 29(4), 192-199. https://doi.org/10.32598/jhnm.29.4.19 2

Anggarini, I. A., Hakimi, M., \& Hidayat, A. (2017). Pengaruh Senam Nifas Terhadap Perubahan Maternal Depressive Symptoms Di Rumah Sakit Ibu dan Anak (RSIA) Sakina Idaman Kabupaten Sleman. Retrieved from http://digilib.unisayogya.ac.id/2403/1/ Naskah Publikasi Inge Anggi\%0AAnggarini_201420102020Copy.pdf

Arlinghaus, K. R., Markofski, M. M., \& Johnston, C. A. (2017). Reducing Anxiety to Increase Exercise in Individuals With Decreased Lung Capacity.,. American Journal of Lifestyle Medicine, 11(4), 307.

Aziz Ismail, N. I. A., \& Elgzar, W. T. I. (2018). The Effect of Progressive Muscle Relaxation on Post Cesarean Section Pain, Quality of Sleep and Physical Activities Limitation. International Journal of Studies in Nursing, 3(3), 14. https://doi.org/10.20849/ijsn.v3i3.461

Bentelu, F. E. M., Kundre, R., \& Bataha, Y. B. (2015). Perbedaan Tingkat Kecemasan dalam Proses Menyusui Antara Ibu Primipara dan Multipara Di RS Pancaran Kasih GMIManado. E-Journal. Retrieved from

https://media.neliti.com/media/public ations/107090-ID-perbedaantingkatkecemasan-\%0Adalamproses.pdf

Fallon, V., Halford, J. C. G., Bennett, K.M., \& Harrold, J. A. (2016). The Postpartum Specific Anxiety Scale: development and preliminary validation. Archives of Women's Mental Health, 19(6), 10791090. https://doi.org/10.1007/s00737016-0658-9

Gökşin, İ., \& Ayaz-Alkaya, S. (2018). The Effectiveness of Progressive Muscle Relaxation on the Postpartum Quality of Life: A Randomized Controlled Trial. Asian Nursing Research,
12(2),86-90.

https://doi.org/10.1016/j.anr.2018.03.0 03

Golmakani, N., Sadat, F., Ahmadi, S., Taghi, M., \& Pour, N. A. (2015). Comparing the Effects of Progressive Muscle Relaxation and Guided Imagery on Sleep Quality in Primigravida Women Referring to Mashhad Health Care Centers -1393. Journal of Midwifery and Reproductive Health, 3(2), 335-342.

Kirana, R. (2015). Hubungan Tingkat Kecemasan Post Partum dengan Kejadian Post Partum Blues Di Rumah Sakit Dustira Cimahi. Jurnal Ilmu Keperawatan, 3(1), 2338-7246.

Lowdermilk, Perry, C. (2013). Keperawatan Maternitas (8th ed.; Kathryn Rhodes Alden, ed.). Singapura: Elsevier Ltd.

Muller, A., \& Hammill, H. (2015). The Effect of Pilates And Progressive Muscle Relaxation Therapy (Mrt) on Stress and Anxiety During Pregnancy: a Literature Review. South African Journal of Sports Medicine, 27(6), 53. Retrieved from www.ijhssnet.com

Ospina, A., Muñoz, L., \& Cardenas, C. D. (2012). Copping and Adaptation process Durring Puerperium. Retrieved from , 43(2), 168-175.

Rahayu, E. S., \& Dwi Heppy Rochmawati, P. (2014). Pengaruh terapi relaksasi otot progresif terhadap penurunan tingkat kecemasan pada klien diabetes mellitus tipe 2 di Wilayah Kerja Puskesmas Karangdoro Semarang. 41.

Rahmawati, P. M., Widjajanto, E., \& Astari, A. M. (2017). the Influence of Progressive Muscle Relaxation on Anxiety Level of Pre-Caesarean Section Mothers in Delivery Room. NurseLine Journal, 2(2), 117. https://doi.org/10.19184/nlj.v2i2.5929

Shaw, R. J., John, N. S., Lilo, E. A., Jo, B., Benitz, W., Stevenson, D. K., \& Horwitz, S. M. (2013). Prevention of traumatic stress in mothers with preterm infants: A randomized controlled trial. Pediatrics, 132(4).

https://doi.org/10.1542/peds.2013-1331 
Sulastri, W. (2016). Hubungan Tingkat Kecemasan Ibu dengan Pemberian Asi pada Masa Nifas Di Puskesmas Umbulharjo I Yogyakarta Tahun 2016.

Sumantri, Susilowati, D., \& Wati, D. K. (2016). Kecemasan Ibu Nifas Menggunakan Totok Wajah Di Fasilitas Pelayanan Persalinan. Jurnal Kebidanan Dan Kesehatan Tradisional, 1(1), 1-99.

Thurgood, S., Avery, D. M., \& Williamson, L. (2009). Postpartum Depression (PPD). American Journal of Clinical Medicine ${ }^{\circledR} \quad$ Spring, $\quad 6(2)$. 